\title{
A case of thoraco-omphalopagus conjoined twins with intrauterine death
}

\section{Rosy Khanam*, Shabir Ahmed Choudhury}

Department of Obstetrics and Gynaecology, Silchar Medical College and Hospital, Silchar, Assam, India

Received: 24 August 2021

Accepted: 28 September 2021

\section{*Correspondence:}

Dr. Rosy Khanam,

E-mail: khanamrosy7@gmail.com

Copyright: () the author(s), publisher and licensee Medip Academy. This is an open-access article distributed under the terms of the Creative Commons Attribution Non-Commercial License, which permits unrestricted non-commercial use, distribution, and reproduction in any medium, provided the original work is properly cited.

\begin{abstract}
Conjoined twins or Siamese twins are identical twins that are joined in utero. The original Siamese twins were born in Siam (now Thailand) in 1811. They were males and lived for about 62 years. Incidence being 1 in 49,000 births to 1 in $1,89,000$ births, this phenomenon is very rare. Approximate half are stillborn and one- third die within 24 hours of birth. Five types of conjoint twins are classically described, thoracopagus, omphalopagus, pygopagus, ischiopagus and craniopagus. With a reported incidence of $74-75 \%$ of all conjoint twins, Thoracopagus is the most common type. Omphalopagus with an incidence of $0.5 \%$ is the least common. Here we are reporting a case of thoraco-omphalopagus twin pregnancy with intra uterine death delivered by hysterotomy.
\end{abstract}

Keywords: Conjoined twins, Thoracopagus, Omphalopagus, Intrauterine death, Hysterotomy

\section{INTRODUCTION}

Conjoined twins are popularly known as Siamese twins. The original Siamese twins were born in Siam (now Thailand) in 1811. They were males and lived for about 62 years. Conjoined twinning results from late twinning of a single zygote. Conjoined twins share a single common chorion, placenta and amniotic sac. However, these features are not unique for conjoined twins, as some monozygotic twins who are non-conjoined share the same structures. Similar to all monozygotic twins, all conjoined twins also have the same sex. ${ }^{1,2}$

Most common form of conjoined twins is fusion of the anterior thorax and/or abdomen (referred to as thoracopagus, omphalopagus and thoraco-omphalopagus), which altogether constitutes $70 \%$ of conjoined twins. ${ }^{2}$ Increased nuchal fold thickness has been documented in multiple cases of conjoined twins. It is mainly associated with thoracopagus conjoined twins. ${ }^{3}$

Incidence being 1 in 49,000 births to 1 in 1,89,000 births, this phenomenon is very rare. ${ }^{4}$ Approximate half are stillborn and one- third die within 24 hours of birth. ${ }^{5}$ With a reported incidence of $74-75 \%$ of all conjoint twins, thoracopagus is the most common type. Omphalopagus with an incidence of $0.5 \%$ is the least common. ${ }^{6}$

\section{CASE REPORT}

Mrs. A, 28 years old un-booked female, G2P1L1, previous child delivered by normal vaginal delivery 2 years back, attended department of obstetrics and gynaecology, Silchar medical college and hospital for antenatal check up on 01-08-2021 with history of 5 months amenorrhea. Her last menstrual date was unknown. The patient was normotensive with normal findings on general and obstetric examination. She had no personal or family history of twins. Transabdominal sonography was performed as routine procedure and two foetuses at 23 weeks gestation with 2 arms, legs and hands were visualised. Twins being joined at thorax and abdomen. There was a single umbilical cord. Placenta was localized posteriorly and one artery and one vein were seen in umbilical cord. There was absent fetal movements with absent fetal cardiac activity. There were congenital 
anomalies in both the twins. All the routine investigations needed in a case of intrauterine death were done and were in the range of normal values. Since the conjoined twin foetus were both case of intrauterine death, the patient and her husband were explained about the condition and they decided to go for termination of pregnancy by hysterotomy after proper explanation of the procedure.

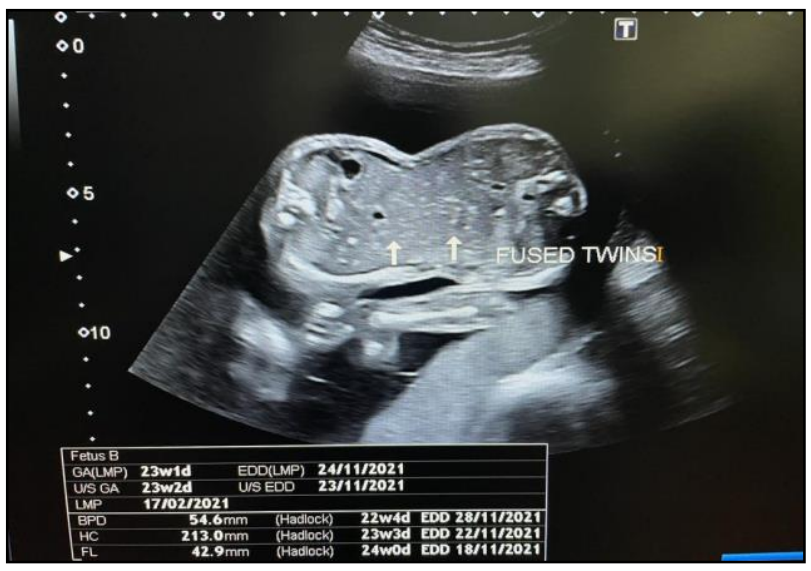

Figure 1: Ultrasonography of fused twins.

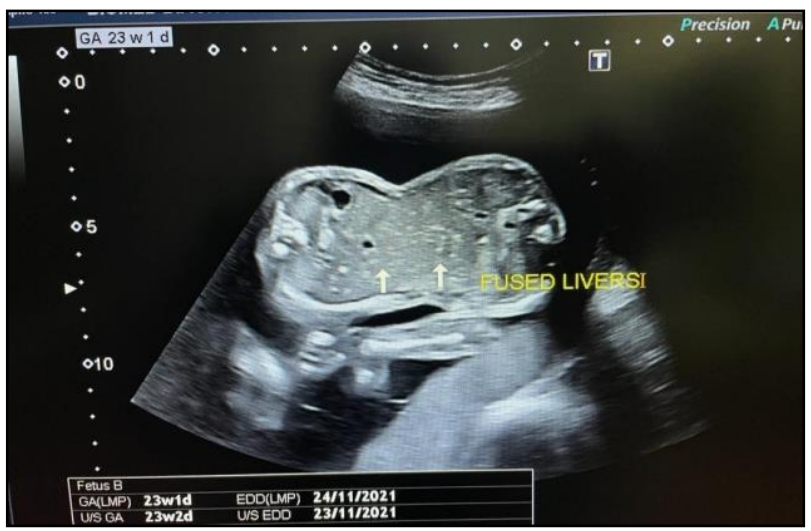

Figure 2: Ultrasonography of twins with fused livers.

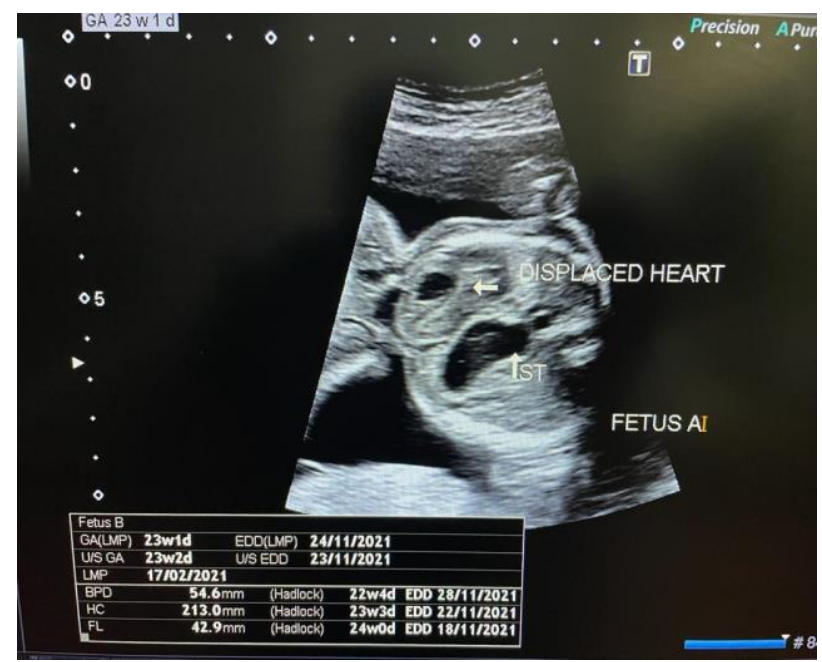

Figure 3: Ultrasonography of twin 1 with displaced heart.

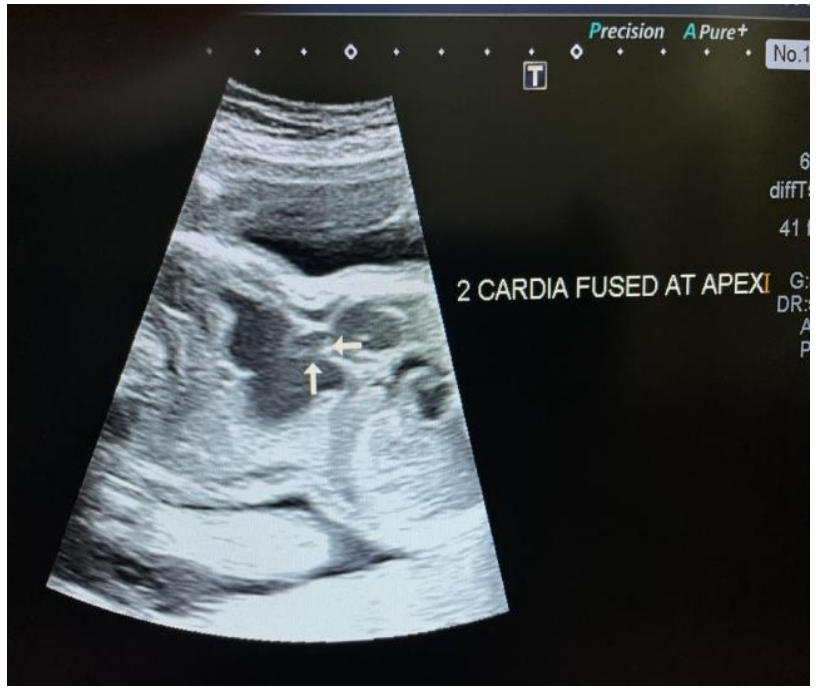

Figure 4: Ultrasonography of twins with hearts fused at apex.

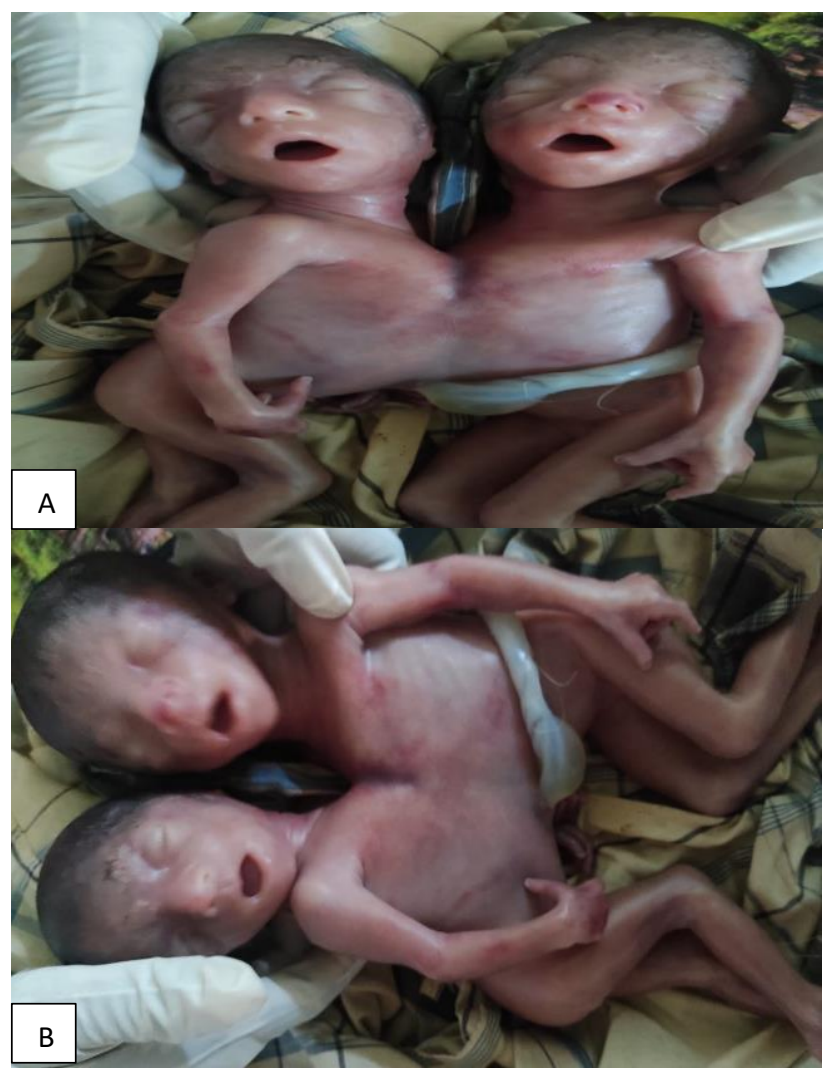

Figure 5 (A and B): Thoraco-omphalopagus twin intrauterine death.

\section{DISCUSSION}

According to the most prominent site of conjunction, conjoined twins are classified into: thorax (thoracopagus), abdomen (omphalopagus), sacrum (pygopagus), pelvis (ischiopagus), skull (cephalopagus), and back (rachipagus). Various classification systems have been proposed for this defect. 
Spencer classified conjoined twins on the basis of site of union i.e.: ventral or anterior union (cephalopagus, thoracopagus, omphalopagus, ischiopagus, and parapagus) and dorsal or posterior union (craniopagus, pyopagus, and rachipagus), while Potter and Craig simply classified on the basis of most common forms of twinning. ${ }^{6}$

The most common types are thoracopagus (19\%) depending on the aspect of the embryonic disc. ${ }^{7}$ Its etiology is unknown, but an incomplete division of the zygote between $13^{\text {th }}$ and $15^{\text {th }}$ days after fertilization probably occurs. ${ }^{8}$ The overall survival rate for conjoined twins is approximately $25 \%$. $^{9}$

Surgical separation of conjoined twins was first attempted in 1950. The first successful pyopagus twin separation was performed in Louisiana in 1953. Many cases are successfully separated in different parts of the world with the development of microsurgery and cardio-vascular surgery. ${ }^{10}$ However, for ethical reasons, surgery should not be attempted if it deemed to be hazardous or if it may scarify or disable one twin for the sake of the others. ${ }^{11}$

Multi-disciplinary approach of an experienced team is needed for successful surgical separation of conjoined twins. ${ }^{12}$ The separation of conjoined twins has long been a surgical challenge.

Sometimes emergency conditions may necessitate emergency separation. ${ }^{13}$ Sometimes critical condition of one twin may necessitate emergency separation. ${ }^{13,14}$

Monochorionic mono-amnionic twin pregnancies are at increased risk of fetal death, signaling a need for increased levels of monitoring. Causes for intrauterine death being placental, congenital anomalies, TTTS. ${ }^{15,16}$ In our case as in ultrasonography findings were suggestive of one twin having Ventricular Septal defect and the other with atrioventricular septal defect with gross polyhydramnios.

Decision for continuation or termination of pregnancy depends on the case concerned and should preferably be individualised depending on facilities available regarding pediatric care.

Since ours was case of both twins with intrauterine death, decision for termination had to be considered. Both the conjoined twin fetus were case of intrauterine death at 23 weeks gestation, patient and her husband took decision for terminating the pregnancy by hysterotomy providing proper consent for the procedure.

\section{CONCLUSION}

In spite of the technological and surgical advancements, mortality of conjoined twins remains high. Also, the separation techniques are possible yet complicated and survival of the babies becomes difficult. When severe forms of conjoined twins are diagnosed prior to 24 weeks gestation, termination via vaginal delivery may be considered. In our case, the conjoined twins were joined at the chest and the abdomen forming a thoracoomphalopagus with intrauterine death. The diagnosis was made in the second trimester (23 weeks gestation) and the family chose termination. The pregnancy was terminated by hysterotomy owing to a lack of clear local guidelines and experience in dealing with a condition of this rarity with patient and her family opting for the same. Early correct prenatal diagnosis is essential for better obstetric management and treatment planning. Ultrasound is the modality of choice for prenatal detection of conjoined twins. Termination of pregnancy, especially at a late stage, is seen with problems. There are also social and legal issues with late termination, mainly influenced by cultural and religious faith. This stresses the need for early and accurate diagnosis to enable a correct management plan, thus dealing with those potential complications.

\section{Funding: No funding sources \\ Conflict of interest: None declared \\ Ethical approval: Not required}

\section{REFERENCES}

1. Osmanağaoğlu MA, Aran T, Süleyman G, Kart C, Ozgür O, Bozkaya H. Thoracopagus conjoined twins: a case report. Obstet Gynecol. 2011;2011:238360..

2. Sharma UK, Dangol A, Chawla CD, Shretha CD. Antenatal detection of conjoined twin. J Nepal Med Assoc. 2007;46:133-5.

3. Ratner AN, Terrone D, Cosgrove FJ. Thoracopagus conjoined twins. J Diagn Med Sonog. 2006;22:53-5.

4. Conjoined Twins Facts. University of Maryland Medical Center. 2012.

5. Carnevale FC, Marcus VB, Affonso BB, Pinto RP, Uenis T, João GM. Importance of angiographic study in preoperative planning of conjoined twins: case report. Clinics. 2006;61(2):167-70.

6. Spencer R. Anatomic description of conjoined twins: A plea for standardized terminology. J Pediatr Surg. 1996;3:941-4.

7. O’Neill JA, Rowe MI, Grosfeld JL, Fonkalsrud EW, Coran AG. Conjoined Twins: in Pediatric Surgery. Mosby. 2006;9:2080.

8. Schnaufer L. Conjoined twins," in Swenson's Pediatric Surgery. Raffensperger JG Ed. Appleton Century-Crofts, New York, NY, USA, $4^{\text {th }}$ edition, 1980;910-20.

9. Abossolo T, Dancoisne P, Tuaillon J, Orvain E, Sommer JC, Rivière JP. Early prenatal diagnosis of asymmetric cephalothoracopagus twins. J gynécol, obstétri boil reproduct. 1994;23(1):79-84.

10. Stone JL, Goodrich JT. The craniopagus malformation: classification and implications for surgical separation. Brain. 2006;129(5):1084-95.

11. Kamak I, Ciftei AO, Buyukpcmukcu N. Epigastric Heteropagus: a case report with review of the literature. Eur J Pediatr Surg. 1999;9(5):347-50. 
12. Groner JI, Teske DW, Teich S. Dicephalus dipus dibrachius: an unusual case of conjoined twins. J. Pediatr Surg. 1996;31(12):698-700.

13. Al Rabeeah A. Conjoined Twins-past, present and future. J. Pediatr Surg. 2006;41(5):1000-4.

14. Shapiro E, Fir WR, Ternberg JL, Siegel MJ, Bell MJ, Manley CB. Ischiopagus tetrapus twins: Urological aspects of separation and 10 years follow up. J Urol. 1991;145:120-5.

15. Dorig AT. Successful separation of ischiopagus tripus conjoined twins with one twin suffering from brain damage. J PeSiatr Surg. 1993;28:965-8.
16. Stauffer JG. Conjoined twins. In Neo natal Surgery, $3^{\text {rd }}$ edn. Eds Lister J, Irving IM, London, Butterworths. 1990;153-62.

17. Sabih D, Ahmad E, Sabih A, Sabih Q. Ultrasound diagnosis of cephalopagus conjoined twin pregnancy at 29 weeks. Biomed Imaging Interv J. 2010;6(4):e38.

Cite this article as: Khanam $\mathrm{R}$, Choudhury SA. A case of thoraco-omphalopagus conjoined twins with intrauterine death. Int J Reprod Contracept Obstet Gynecol 2021;10:4319-22. 